\title{
Comic books: technology in health for the humanization of care delivery to hospitalized children
}

\author{
História em quadradinhos: tecnologia em saúde para a humanização da assistência à \\ criança hospitalizada \\ Novela gráfica: tecnología en la salud para la humanización de la asistencia al niño \\ hospitalizado
}

Karla Maria Carneiro Rolim*; Carlon Washington Pinheiro**; Fernanda Jorge Magalhães**;

Mirna Albuquerque Frota****; Francisco Antônio da Cruz Mendonça*****;

Henriqueta Ilda Verganista Martins Fernandes******

\begin{abstract}
Background: The use of a comic book (CB) on a painful and stressful procedure in pediatrics may contribute to a more humanistic practice, leading to a better understanding of children's subjective needs and improved care quality. Objective: To describe the experience of the elaboration and use of a comic book (CB) about the instructional therapeutic toy (ITT) on venipuncture, following the assumptions of the humanistic nursing theory.

Methodology: Experience report with a qualitative, educational, and humanistic approach on the elaboration of the $\mathrm{CB}$ on venipuncture based on Paterson and Zderad's humanistic theory at a pediatric unit in Fortaleza, Ceará, Brazil.

Results: Self-explanatory, instructive, disseminating, humanizing, and original texts and illustrations were elaborated based on typographic drawings of the stages of the venipuncture procedure, as ITT, and using the vocabulary of surveyed nursing professionals.

Conclusion: The use of $\mathrm{CB}$ as a health technology is believed to improve nursing care and practice, as well as for raising professionals' awareness to the adoption of a humanized practice. A limitation of this study was the difficulty in generalizing results.
\end{abstract}

Keywords: pediatrics; nursing care; hospitalization; health education

\section{Resumo}

Enquadramento: A utilizaçáo de uma história aos quadradinhos (HQ) acerca de um procedimento doloroso e stressante na pediatria pode contribuir para uma prática humanística, com a compreensáo das necessidades subjetivas da criança e melhoria da qualidade da assistência.

Objetivo: Descrever a experiência da elaboraçáo e utilizaçáo de uma história aos quadrinhos (HQ) acerca do brinquedo terapêutico instrucional (BTI) sobre punção venosa, seguindo os pressupostos da teoria humanística de enfermagem.

Metodologia: Relato de experiência, com abordagem qualitativa, de cunho educativo e humanístico, sobre a elaboração da HQ acerca do procedimento de punção venosa, com apoio na teoria humanística de Paterson e Zderad, numa unidade pediátrica de Fortaleza-Ceará-Brasil.

Resultados: Elaboraram-se textos e ilustraçóes autoexplicativas, instrutivas, divulgadoras, humanizadoras e inéditas, a partir de desenhos tipográficos das etapas da realizaçáo do procedimento de punção venosa, como BTI, e tomando como base o léxico dos profissionais de enfermagem pesquisados.

Conclusáo: A tecnologia em saúde da HQ pode trazer implicaçóes para a prática quanto à assistência de enfermagem, bem como a sensibilização de profissionais para adoção de uma prática humanizada. Como limitaçáo, cita-se a dificuldade de generalizaçáo dos resultados.

Palavras-chave: pediatria; cuidados de enfermagem; hospitalização; educação em saúde

*Ph.D., RN, University of Fortaleza, 60000-100, Ceará, Brazil [karlarolim@unifor.br].Contribution to the article: literature search, data collection, and article writing. Address for correspondence: to the article: literature search, data collection
Rua Silva Paulet, 60120-021, Ceará, Brazil.

Rua Silva Paulet, 60120-021, Ceará, Brazil.
**Bacharelato, Student, University of Fortaleza, 60000-100, Ceará, Brazil [carlon.washington@ edu.uniforbr] Contribution to the article: literature search, deara, Brazil [Carlon.washington edu.unifor.br. . Contribution to the article: literature search, data collection, and article writing. ***Ph.D., Professor, Federal University of Ceará, 6043000 , Ceará, Brazil [fernandajmagalhaes
vahoo.com.br]. Contribution to the article: data analysis and discussion, and article writing. yahoo.com.br]. Contribution to the article: data analysis and discussion, and article writing. ***: Ph.D., RN, University of Fortaleza, 60000-100, Ceará, Brazil [mi

tion to the article: data analysis and discussion, and article writing.
******Ph.D., RN, Centro Universitário Estácio do Ceará, 60000-100, Ceará, Brazil [mendoncafac@ hotmail.com]. Contribution to the article: discussion and article writing.

*******..com.D., RN, Nursing School of Porto, 4200-072, Porto, Portugal [ildafernandes@esenf.pt]. Contribution to the article: data analysis and discussion, and article writing.

\section{Resumen}

Marco contextual: Emplear un cómic (HQ, en portugués) sobre un procedimiento doloroso y estresante en pediatría puede contribuir a la práctica humanística, mediante la comprensión de las necesidades subjetivas del nińo y la mejora de la calidad de la asistencia.

Objetivo: Describir la experiencia de elaborar y utilizar una novela gráfica (HQ) acerca del juguete terapéutico instructivo (BTI) sobre la punción venosa, siguiendo los presupuestos de la teoría humanística de enfermería.

Método: Relato de experiencia, con enfoque cualitativo, educativo y humanístico, sobre la elaboración de la HQ acerca del procedimiento de punción venosa, con base en la teoría humanística de Paterson y Zderad, en una unidad pediátrica de Fortaleza (Ceará, Brasil).

Resultados: Se elaboraron textos e ilustraciones autoexplicativas, instructivas, divulgadoras, humanizadoras e inéditas, a partir de dibujos tipográficos de las etapas del procedimiento de punción venosa, como BTI, y tomando como base el léxico de los profesionales de enfermería investigados.

Conclusión: La tecnología en salud de la HQ puede tener implicaciones para la práctica en cuanto a la asistencia de enfermería, así como la sensibilización de profesionales para la adopción de una práctica humanizada. Como limitación se cita la dificultad de generalización de los resultados.

Palabras clave: pediatría; atención de enfermería; hospitalización; educación en salud

Received for publication: 27.03 .17

Accepted for publication: 01.06 .17 


\section{Introduction}

The theoretical and visual framework of comic books (CB) points to a positive impact on the promotion of children and young people's reading skills, creativity, and reasoning. It was, along with cinema, the most important means of mass communication of the $20^{\text {th }}$ century, having expanded since the 1930 s to virtually every country in the world. CB enable the recreational interaction between the reader and the text, providing challenges and discoveries that are mediated by imagination and language (Kawamoto \& Campos, 2014; Santos, Urbinati, \& Santos, 2015).

The process of producing health-related $\mathrm{CB}$, particularly for pediatric nursing, has the potential to promote a more humanistic care delivery. Through CB, the reader is able to understand children's needs and feelings, allowing them to play an active role during care delivery itself. Children's fears and concerns are projected in an external environment, as well as possibilities of understanding and adoption of different attitudes toward situations and problems experienced during hospitalization (Silva, Jesus, Santos, \& Martins, 2010).

In this context, the study aimed to describe the experience of volunteers of the $A n$ jos da Enfermagem (Nursing Angels) program during the elaboration and use of a $\mathrm{CB}$ about the instructional therapeutic toy based on the assumptions of the Humanistic Nursing Theory.

\section{Background}

When used as a health technology in care delivery to hospitalized children, $\mathrm{CB}$ can be conceptualized as a therapeutic toy (TT). There are three types of therapeutic toys: the dramatic therapeutic toy (DTT), the therapeutic toy for physiological function (TTPF), and the instructional therapeutic toy (ITT). Therefore, when nursing interventions/actions to the child/family in hospital settings are performed through creativity and art, they strengthen communication and interpersonal relationships, allowing for a greater cooperation between professionals/ child/family or tutor/accompanying person, thus expanding care humanization and leading to positive outcomes (Catrib \& Oliveira, 2012).

The Anjos da Enfermagem: educação e saúde através do lúdico (Nursing Angels: education and health through play) program is composed of volunteers. This program is funded by the Brazilian Federal Nursing Council (Conselho Federal de Enfermagem, COFEN) and supported by the Regional Boards of Nursing (Conselhos Regionais de Enfermagem, COREN) and universities. Its main mission is to provide support to hospitalized children and build a humanistic vision on health education practices through recreational activities, with moments of relaxation and participation, in order to encourage the interaction and communication between volunteers and hospitalized children. In this way, playful activities are able to minimize hospitalized children's traumatic situations and adaptation difficulties, while promoting joy and smiles, and improving the professional/child/family interaction (Pinheiro, Teixeira, Mendonça, Rolim, \& Duarte, 2014; Cruz, Rocha, \& Marques, 2013).

The impact of this social responsibility project, which is considered to be the most important project in Brazilian nursing, is evidenced by the teaching, research, and outreach activities created with the purpose of developing and strengthening citizenship, through volunteer work, and improving academic and professional training (Vieira, 2012; Cruz \& Acosta, 2014).

In undergraduate nursing courses, humanization is a recurring topic; however, due to the biomedical culture, the same level of attention is still not given to the nuances of the health-illness process. In the late 1980s, Paterson and Zderad put forward the humanistic nursing theory, which is permeated by the human context and lies on the assumptions of unique and individualized dialogue, meeting, presence, relating, and call and response (Paterson \& Zderad, 1988). Such assumptions are intended to promote a more effective and humanistic communi- 
cation (Oliveira, Salvador, \& Santos, 2012). The theory is influenced by existentialism, humanism, and phenomenology, citing writers such as Husserl, Buber, Marcel, and Nietzsche, among others (Paterson \& Zderad, 1988).

Humanistic nursing is linked to individuals' experiences as phenomena in their lives and their development. The inter-human relationship aims to care not only for the person's well-being, but also to help them to get better, to become their best possible self. Since nursing is a process that occurs between people, through which they both can affect and be affected with the possibility of becoming better, it is necessary to know the values, prejudices, myths, and expectations of those involved (nurses and patients) in this process.

\section{Research question}

What are the procedures for elaborating and using $\mathrm{CB}$ in venipuncture procedures to hospitalized children?

\section{Methodology}

A descriptive case report study was conducted on the experiences of four students and three coordinators of the Anjos da Enfermagem program of the Ceará Department, about the preparation and use of a $\mathrm{CB}$ entitled Os Anjos da Enfermagem em: O Brinquedo Terapêutico (Nursing Angels in: The Therapeutic Toy). This study had a qualitative, educational approach based on the assumptions of Paterson and Zderad's Humanistic Theory (1988). It was carried out from March to May 2016 at a pediatric hospital of reference in Fortaleza-Ceará, Brazil. Every year, the volunteers of the Anjos da Enfermagem program are selected in a process that is carried out by the State and local coordinators and instructors. Applicants are interviewed and observed through dynamics regarding their relationship with the other applicants, empathy, and creativity, as well as their academic background. The selected volunteers receive training, through lectures and workshops, about art therapy using music, balloons, paintings, body expression, and theater, and guidance on the interaction with hospitalized children through playful health education.

This training focuses on the delicacy of touch, the importance of speech, smile, eye contact, and of better understanding the child who is away from his/her social life, providing moments of joy in order to alleviate the anguish and pain experienced during hospitalization.

Before the experiences, the volunteer students receive training on patient's rights, nursing legislation, notions of prevention and control of hospital-acquired infections and scientific methodology, considering the need for the development of research studies.

During in-hospital visits, which are previously authorized by the board of directors of the pediatric hospital, the volunteers, supervised by the coordinators, develop playful health education activities to children undergoing cancer treatment and interact with them and their families.

The purpose of using health education strategies is not only to convey information, but also to provide moments for sharing life experiences and emphasizing behavioral aspects and therapeutic measures experienced in different national and international realities (Sposito, Sparapani, Pfeifer, Lima, \& Nascimento, 2013).

Several playful activities oriented toward health education are carried out, such as art with balloons and paintings, story-telling, drawings, magic, music therapy, theater, among others. These activities aim to reduce the feelings of fear and anxiety resulting from the hospital admission process and chemotherapy (Pinheiro et al., 2014).

At that moment, the volunteer student tries to understand the process that will be experienced, setting goals for restructuring care delivery, and seeking to promote a dialogic relationship, through a more humanized care. When facing children in distress and suffering as a result of the disease and associated pain, the volunteer must understand their anxieties and fears, looking to establish a relationship and demonstrate a genuine presence.

According to the Humanistic Theory, this 
encounter, in which there is a purposeful call and response, is one of the goals of nursing, which uses this theory as art, in a significant and effective manner, leaving a lasting impression and demonstrating that people can fight to become everything that they are able to be (Paterson \& Zderad, 1988).

Therefore, to work with children undergoing cancer treatment, the volunteer needs to possess a range of playful strategies, such as the pedagogical proposal brought by art therapy. This strategy has been applied to education, with an emphasis on psychomotricity, in which children develop the necessary motor skills for personal and interpersonal development through activities such as modeling, drawing, painting, models, music, and puppet theater (Malagutti \& Kakihara, 2014).

Thus, being present is the quality of being receptive, perceptive, and ready; through his/ her presence, the volunteer must show cognitive and emotional availability. Calls and responses are understood as the child/volunteer communication to the extent that the call and response should occur simultaneously. This entire dialogical process should be experienced through words, looks, attitudes, voice tone, and facial and body expression, demonstrating the importance of an efficient communication for an effective care delivery and promoting communication in a holistic and integral way (Lima, 2015).

During the observations, the professional is often immersed in impersonality, the genuine interaction with the child is damaged and the professional expects only expressions and collaborative actions from the child, followed by acceptable attitudes and behaviors. This way of being denies personal responsibility, resulting in superficial acts and languages that do nothing to enhance the understanding of those involved (Melo \& Valle, 2010).

With regard to the elaboration of the CB, the first step was the selection of the main nursing care activities to be addressed by the Anjos da Enfermagem volunteers during recreational activities. Venipuncture was the chosen procedure given the feelings of distress, nervousness, and pain experienced by children. Texts and graphic illustrations were created based on the above-mentioned theoretical assumptions. The illustrations were first handmade by a designer with artistic skills who was willing to collaborate in the study. The designer did the drawings as requested and described by the researchers. Later, the drawings were retouched using the Adobe Photoshop CC software. Finally, the texts and illustrations were formatted using this software.

The study followed the ethical principles of Resolution 466/12 of the National Health Council, in accordance with approval opinion no. 1.444.510 (Resolution 466/2012/ CNS/MS/CONEP).

\section{Results}

The CB Os Anjos da Enfermagem em: O Brinquedo Terapêutico has an informative and educational purpose for nursing professionals and hospitalized children. This technology used the following format: $21 \mathrm{~cm}$ in height and $29.7 \mathrm{~cm}$ in width on each page, with 11 sheets, divided into CB cover and contents, in a total of 10 pages.

The contents include original images, which are instructive, self-explanatory, and able to convey knowledge. The images were designed based on photographs taken of the hospital's façade but tried to create a more colorful and playful hospital environment with a view to portraying both the reality experienced in the unit and the child's playful universe.

The aesthetics and the text were portrayed in simple pictures and with minimal words. The cover of the CB is consistent with its content, clear, and in harmony with the logo of the Anjos da Enfermagem program. The illustrations were distributed on a light blue background with clouds, an analogy between the Anjos da Enfermagem program and the sky (Figure 1). 


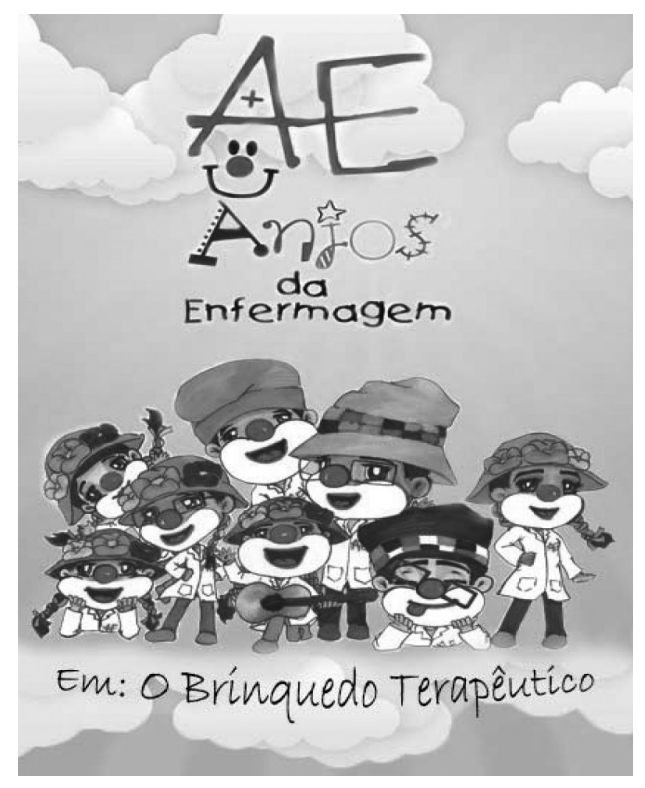

Figure 1. Cover of the CB Os Anjos da Enfermagem em: O Brinquedo Terapêtico.

Both primary and secondary colors were used. The characters were dressed up as clowns using strong and vibrant colors (Figure 2). The choice of these colors resulted from the expe- rience of the Anjos da Enfermagem volunteers, who always use them to assist in the interventions as clowns, for example making paintings and balloons.

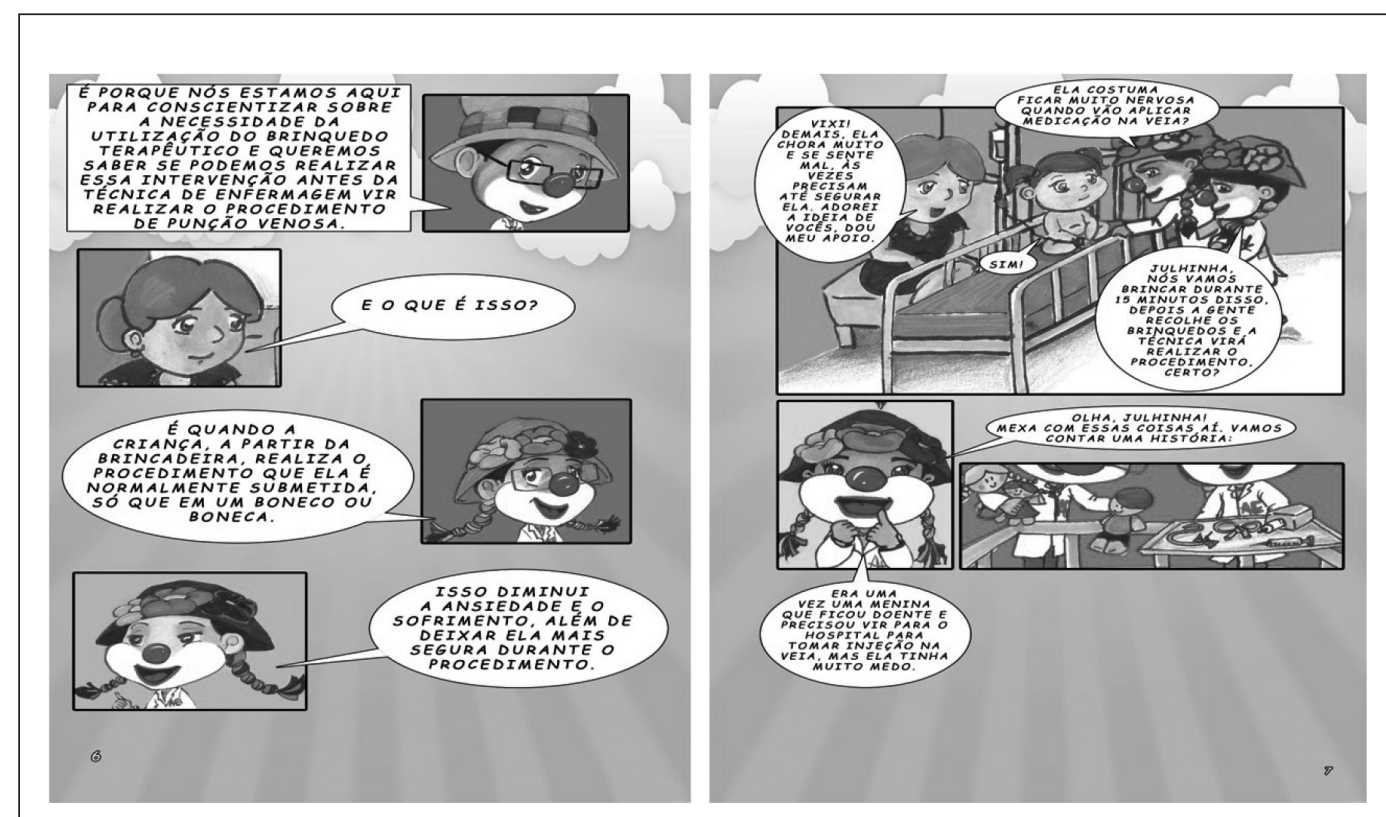

Figure 2. Worksheets 6 and 7 of the CB Os Anjos da Enfermagem em: O Brinquedo Terapêutico 
The most important situation in the $\mathrm{CB}$ is the moment in which the steps for handling the ITT are performed by the characters. The first step is taken by the volunteers who approach the child and the accompanying person, as the mother in the $\mathrm{CB}$.

In the $\mathrm{CB}$, the volunteers, dressed up as clowns, explain to the mother the reason why they are in the hospital, tell about the benefits of the therapeutic toy for the hospitalized child's health, and clarify the mother's doubts. The contact with family members to address the therapeutic toy's purposes is an essential step for a successful process.

On the next page, two angels ask the mother about the child's nervousness during venipuncture. The mother says that the child becomes not only anxious but also sick. In addition, in this situation, an Anjos da Enfermagem volunteers enters the scene and oth- ers bring dolls and the hospital equipment for the venipuncture.

At this moment, there is a dialogue with the child and, 15 minutes later, the toys are collected. Establishing a moment for ending the intervention with the child is essential for the intervention to end in the less traumatic way possible and in a collaborative way.

It should be noted that, while the girl plays with the doll and the hospital equipment, the characters begin to tell the story of a litthe girl who was afraid of the vein injection and always needed many people to grab her. They continued telling that the situation improved because she realized that the cotton was used to clean the skin, the little rubber was used to see the vein, and the needle was used for the medicine to enter the body and make her feel better (Figure 3).
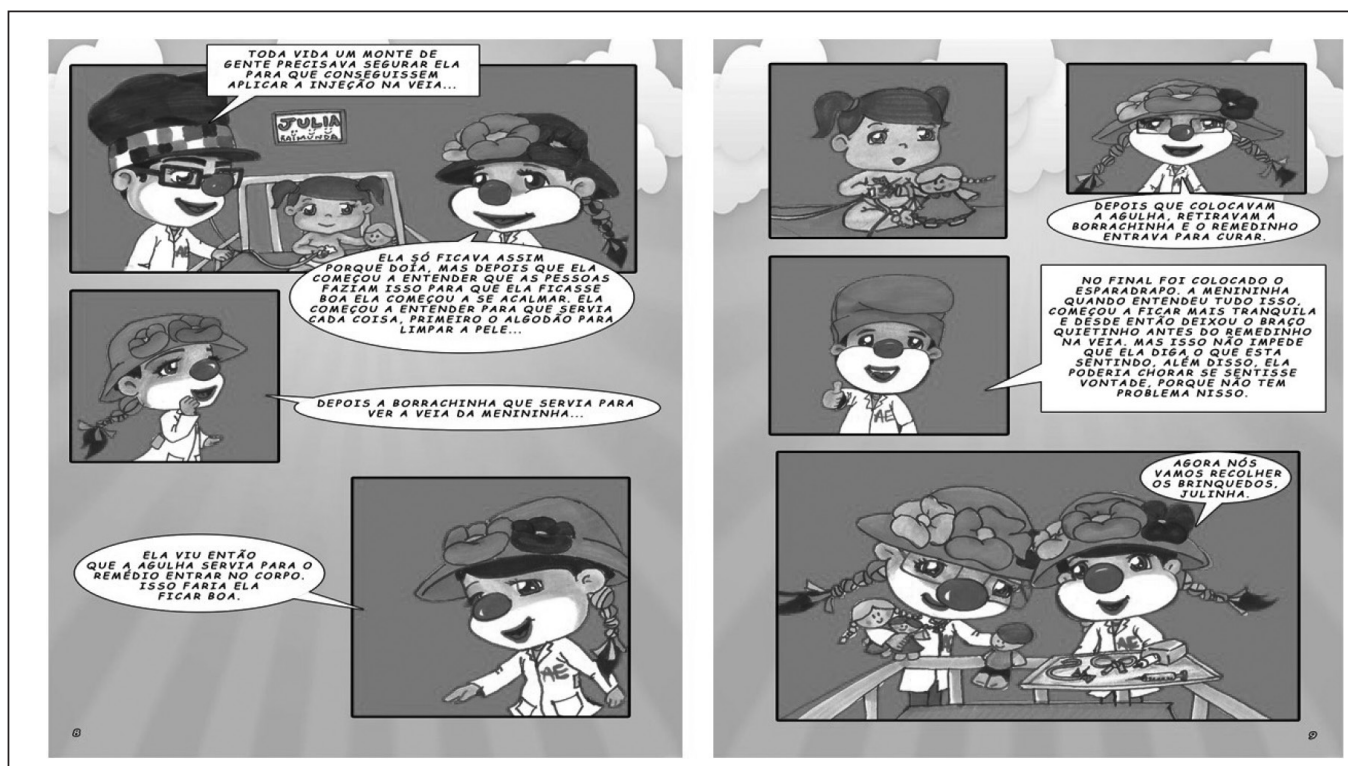

Figure 3. Situations described in pages 8 and 9 of the CB Os Anjos da Enfermagem em: O Brinquedo Terapêutico.

This step of story-telling, associated with the act of playing, is relevant, especially for the child to assimilate the contents due to the empathy created with the character described in the story, which is similar to their situation of hospitalization.
The last pages of the CB depict the arrival of the nursing professional who would perform the venipuncture. When asking the girl if she is scared, the professional receives an unexpected answer, which is a statement of courage and confidence to face the procedure with 
the help of her new friends. In the end, the volunteers hold hands and leave the room, saying goodbye to the girl.

\section{Discussion}

The need to use technologies in health care is common in nursing procedures. Hence, the choice of this technology should seek a genuine dialogue, meeting, relating, and presence, so that the process of nursing care can truly be humanistic rather than just apparently so (França, Costa, Lopes, Nóbrega, \& França, 2013).

The health team should be aware of various educational technologies that enable the implementation of instruments that can facilitate the teaching-learning process, focusing on the calls and responses of pediatric patients. The loss of fear of the individuals who provide care makes it a less traumatic experience, precisely due to the sense of security that will be routinely and gradually installed and not just in seldom actions that are sometimes performed for convenience (Oliveira et al., 2012; Malagutti \& Kakihara, 2014).

Studies show that positive emotions can produce positive health outcomes, and that humor and laughter are moderators of painful and stressful situations such as cardiac rehabilitation, pain perception, discomfort, stress hormone modulation, and enhancement of the immune system in children and adults (Bertini, Isola, Paolone, \& Curcio, 2011). The act of playing strengthens the bonds of affection and trust between nursing professionals and the child, facilitating care practices and improving the interaction between caregivers and patients.

The advantage of the $\mathrm{CB}$ is that it is a material with a progressive sequence of pages, with interdependent relations with the story context that are able to guide and lead to reflection on the contents of the topic under analysis, playfully acting out on the interaction of the world, the one who reads with the world, what is manifested. In the universe of CB, language has a poetic role in the symbolic systems that cover the world of metaphors and onomatopoeias, broadening the interaction and dissemination of ideas (Santos et al., 2015).
The adaptation of the $\mathrm{CB}$ context to the awareness about the therapeutic toy brings about mutual benefits from this interaction, associating the positive aspects of both the $\mathrm{CB}$ and the therapeutic toy. Malagutti and Kakihara (2014), in a study on the use of the therapeutic toy, reaffirm that the use of this technology in nursing care, during the assessment of children's behaviors, significantly improved the process of understanding and accepting the painful procedure. In the study, it was also evident that the therapeutic toy was a favorable intervention that improved care delivery and humanized nursing care. It should be emphasized that, before the use of the therapeutic toy, $44.1 \%$ of children smiled, $35.3 \%$ expressed fear, $11.8 \%$ cried, and $32.3 \%$ had muscle tension, whereas, after its use, $85.3 \%$ of children smiled, $11.8 \%$ expressed fear, $8.8 \%$ cried, and $8.8 \%$ had muscle tension (Malagutti \& Kakihara, 2014).

During the experience, the Anjos da Enfermagem volunteers observed that the main barriers to using this technology in the unit included the lack of motivation, devaluation, and work overload at the unit, showing the difficulty in progressively reaching human potentials. The psychosomatic and spiritual dimensions of the human being are not experienced for the benefit of well-being or feeling better and this complicates the process of transcending oneself and, consequently, opening up to others (França et al., 2013).

Humanistic nursing is a live dialogue. In order to understand patients, the professional responds to their calls in the form of intersubjective dialogue that takes place in nursing situations and requires the synchronicity between doing with and being with (Coelho \& Vergara, 2015).

The nurses at the unit believed in the positive impact of the CB and the ITT as a valid technology in health to prepare the child for a venipuncture, taking into account the positive signs transmitted to the Anjos da Enfermagem volunteers such as a smiling, nodding, and waving. In this way, the integration of playing into educational interventions is a key method to encourage children to engage in care delivery, thus facilitating their learning and contributing to health promotion and disease (re)signification. 
However, the integration of playful activities into nursing care is clearly ineffective in Brazilian pediatric health, due to the lack of incentives and related knowledge. These practices are reduced to the mere handling of toys, which does not address the true potential of play therapy (Brito, Resck, Moreira, \& Marques, 2009).

Due to its specificity, the process of caring for pediatric patients is a motivating factor for nurses to provide an individualized response to the child and their family. In addition, there is a need for continuous training of the team and analysis of its practices with a view to maximizing the therapeutic resources, such as $\mathrm{CB}$ and therapeutic toys, and proposing activities that improve nursing care (Mendes \& Martins, 2012).

\section{Conclusion}

To sum up, it was possible to report and describe the experience of developing a $\mathrm{CB}$ about the ITT on venipuncture, following the assumptions of the humanistic nursing theory.

Despite the difficulties in conducting the study, it is necessary to reflect on the importance of having a different perspective on both the patient and the caregiver. The study on the humanistic nursing theory has raised the awareness about the process of human relationship that occurs in nursing situations and has culminated in the development of this $\mathrm{CB}$.

The $\mathrm{CB}$ technology is believed to bring significant benefits to the nursing care provided to pediatric inpatients and raise nursing professionals' awareness about humanized practices. These aspects improve the quality of health services and enhance the relationship between professionals, patients, and families. It should be emphasized that this study describes a pilot experience, whose main limitation was the lack of validation of the $\mathrm{CB}$, which will be done in the future. Further studies should be conducted to assess the impact of $\mathrm{CB}$ and the therapeutic toy on care delivery to hospitalized children so that new scientific evidence emerges to suggest new directions for this area of specialization. The possibility of application of this $\mathrm{CB}$ in nursing professionals' routine of caring for children should be addressed since we believe that this technology fits this purpose.

\section{References}

Bertini, M., Isola, L., Paolone, G., \& Curcio, G. (2011). Clowns benefit children hospitalized for respiratory pathologies. Evidence-Based Complementary and Alternative Medicine, 2011, 1-9. doi:10.1093/ecam/ neq064

Brito, T. R., Resck, Z. M., Moreira, D. S., \& Marques, S. M. (2009). As práticas lúdicas no cotidiano de cuidar em enfermagem pediátrica. Escola Anna Nery Revista Enfermagem, 13(4), 802-808.

Catrib, P. R., \& Oliveira, I. C. (2012). The nursing team strategies for children with communicable diseases. Texto \& Contexto Enfermagem, 21(1), 103-111.

Coelho, N. R., \& Vergara, L. M. (2015). Teoria de Paterson e Zderad: Aplicabilidade humanística no parto normal. Cogitare Enfermagem, 20(4), 829836.

Cruz, A. C., \& Acosta, N. M. (2014). Brincar aprendendo ou aprender brincando? A importância do lúdico para crianças com deficiência intelectual. Revista Pós-Graduação: Desafios Contemporâneos, 1(1), 34-49.

Cruz, D. S., Rocha, S. M., \& Marques, D. K. (2013). O lúdico na hospitalização: Percepção de mães de crianças hospitalizadas quanto ao projeto de extensão "Anjos da Enfermagem". Revista de Ciências da Saúde Nova Esperança, 11(2), 131-42.

França, J. R., Costa, S., Lopes, M. E., Nóbrega, M. M., \& França, I. S. (2013). Importância da comunicação nos cuidados paliativos em oncologia pediátrica: Enfoque na teoria humanística de enfermagem. Revista Latino-Americana de Enfermagem, 21(3), 780-786.

Kawamoto, E. M., \& Campos, L. M. (2014). Comic books as a teaching resource for teaching the human body in initial years of elementary school. Ciência \& Educação (Bauru), 20(1), 147-158.

Lima, I. B. (2015). O diálogo da enfermagem no cuidado a criança hospitalizada: Um caminho em direção à alteridade? Universidade Federal do Rio Grande do Norte. Retrieved from http://monografias.ufrn.br/ jspui/handle/123456789/1753

Malagutti, W., \& Kakihara, C. T. (2014). Curativos, estomia e dermatologia: Uma abordagem multiprofissional ( $3^{a}$ ed.). São Paulo, Brasil: Martinari. 
Melo, L. L., \& Valle, E. R. (2010). The toy library as a possibility to unveil the daily life of children with cancer under outpatient treatment. Revista da Escola de Enfermagem da USP, 44(2), 510-8.

Mendes, M. G., \& Martins, M. M. (2012). Parceria nos cuidados de enfermagem em pediatria: Do discurso à ação dos enfermeiros. Revista de Enfermagem Referência, 3(6), 113-121.

Oliveira, R. K., Salvador, P. T., \& Santos, V. E. (2012). Application of humanistic nursing theory in healthcare: An integrative literature review. Revista de Pesquisa: Cuidado é Fundamental Online, 4(1), 26952704. Retrieved from http://www.seer.unirio.br/ index.php/cuidadofundamental/article/view/1506

Paterson, J. G., \& Zderad, L. T. (1988). Humanistic nursing. New York, NY: National League for Nursing.

Pinheiro, C.W., Teixeira, A.A.S., Mendonça, F.A.C., Rolim, K.M.C., \& Duarte, J. (2014). Projeto anjos da enfermagem: protagonismo na humanização do cuidado a criança portadora de câncer. Anais do $17^{\circ}$ Congresso Brasileiro dos Conselhos de Enfermagem,
Belém, PA, Brasil, 1-13.

Resolução 466/2012/CNS/MS/CONEP. Diário Oficial da União, 12, 59, de 2012. Ministério da Saúde, Conselho Nacional de Saúde, Brasília, Brasil.

Santos, R. E., Urbinati, D., \& Santos, I. L. (2015). História em quadrinhos e a função poética na publicidade. Comunicação Mídia Consumo, 12(34), 89-106. doi: 10.18568/cmc.v12i34.965

Silva, S. H., Jesus, I.C., Santos, R. M., \& Martins, D. C. (2010). Humanização em pediatria: O brinquedo como recurso na assistência de Enfermagem à criança hospitalizada. Pediatria Moderna, 46(3), 101-104.

Sposito, A. M., Sparapani, V. C., Pfeifer, L. I., Lima, R.A., \& Nascimento, L. C. (2013). Estratégias lúdicas de coleta de dados com crianças com câncer: Revisão integrativa. Revista Gaúcha de Enfermagem, 34(3), 30-35.

Vieira, N.H. (2012). Anjos da Enfermagem: A percep̧̧ão dos acadêmicos voluntários do projeto. (Bachelor's Degree). Universidade Regional de Blumenau, Brasil. 
